Т. С. Карпачева Москва

DOI:10.15393/j9.art.2011.318

\section{ОТРАЖЕНИЕ ОБРАЗА СВТ. ТИХОНА ЗАДОНСКОГО И ЕГО СОЧИНЕНИЙ В ТВОРЧЕСТВЕ И МИРОВОЗЗРЕНИИ Ф. М. ДОСТОЕВСКОГО}

Л уховное наследие свт. Тихона Задонского (1724-1783), $\leftrightarrow$ епископа Воронежского и Елецкого, в 1861 году прославленного в лике святых, сыграло огромную роль в истории русской богословской мысли. Прот. Г. Флоровский называет труды святителя «апостольским откликом на безумия вольнодумного века» ${ }^{1}$. Сам облик епископа, вышедшего из бедной крестьянской семьи, был очень близок простому народу. $K$ нему часто обращались за помощью, засвидетельствовано огромное количество чудесных исцелений у мощей святителя. Особой популярностью у народа пользовались краткие проповеди и небольшие по объему сочинения свт. Тихона, распространявшиеся в списках, а впоследствии издававшиеся отдельными брошюрками и листами. Так, наиболее известное сочинение святителя «Христос грешную душу к себе призывает», жанр которого по его эмоциональной насыщенности и художественной выразительности можно было бы вполне определить как стихотворение в прозе, разошлось в сотнях тысяч экземпляров, и в крестьянских избах его вешали оправленным в раму рядом с иконамиㄹ․

\footnotetext{
( ) Карпачева Т. С., 2011
${ }_{1}^{1}$ Флоровский Г. Пути русского богословия. Париж, 1937. С. 124.

${ }^{2}$ Флоровский Г. Пути русского богословия. Париж, 1937. С. 124.
См. об этом: Литвинов В. В. Библиографический указатель литературы о свт. Тихоне Задонском и обзор изданий его творений //
}

Образованный же читатель XIX века, для которого предназначались более объемные и подробные богословские труды святителя «Плоть и дух», «Сокровище духовное, от мира собираемое», «Об истинном христианстве», в большинстве своем к тому времени утратил интерес к духовной литературе. Обращаясь к такому либерально ориентированному читателю, воспитанному на идеях Вольтера, Ф. М. Достоевский в «Дневнике писателя» за февраль 1876 года пишет:

А кстати: многие ли знают про Тихона Задонского? Зачем это так совсем не знать и совсем дать себе слово не читать? Некогда, что ли? Поверьте, господа, что вы, к удивлению вашему, узнали бы прекрасные вещи ${ }^{3}$.

Размышляя над замыслом неосуществленного романа «Житие великого грешника», Ф. М. Достоевский в 1870 году пишет А. Н. Майкову:

Главный вопрос, который проведется во всех частях, тот самый, которым мучился я сознательно или бессознательно всю жизнь, - существование Божие. <...> 2-я повесть будет происходить вся в монастыре. На эту 2-ю повесть я возложил все мои надежды. Может быть, скажут, наконец, что не все писал пустяки. (Вам одному исповедуюсь, Аполлон Николаевич: хочу выставить во 2-й повести главной фигурой Тихона Задонского; конечно, под другим именем, но тоже архиерей, будет проживать в монастыре на спокое). <...> Для других пусть это гроша не стоит, но для меня сокровище. Не говорите же про Тихона. Я писал про монастырь Страхову, но про Тихона не писал. Авось выведу величавую, положительную, святую фигуру. Это уж не Костанжогло-с и не немец (забыл фамилию) в «Обломове», и не Лопухины, и не Рaxметовы. Правда, я ничего не создам, я только выставлю действительного Тихона, которого я принял в свое сердце давно с восторгом. Но я сочту, если удастся, и это для себя уже важным подвигом $(29,1,117-118)$.

Свт. Тихон Задонский. Избранные труды. Письма. Материалы. М., 2004. C. 686.

${ }^{3}$ Достоевский Ф. М. Дневник писателя за 1876 г. // Достоевский Ф. М. Собр. соч.: В 30 т. Т. 22. М., 1981. С. 43. Далее ссылки на произведения Достоевского даются по этому изданию с указанием тома и страницы в тексте арабскими цифрами. 
Через полгода писатель делится своим замыслом и с M. М. Катковым:

Но не все будут мрачные лица; будут и светлые. Вообще, боюсь, что многое не по моим силам. В первый раз, например, хочу прикоснуться к одному разряду лиц, еще мало тронутых литературой. Идеалом такого лица беру Тихона Задонского. Это тоже Святитель, живущий на спокое в монастыре. С ним сопоставляю и свожу героя романа. Боюсь очень; никогда не пробовал, но в этом мире я кое-что знаю $(29(1), 142)$.

В период работы над «Братьями Карамазовыми» Достоевский пишет Н. А. Любимову, указывая на источник «Жћития... старца Зосимы»:

Особенно прошу обратить внимание на корректуру от 10 до 17 полулистка включительно (главка под рубрикой: «О Священном Писании в жизни отца Зосимы»). Эта главка восторженная и поэтическая, прототип взят из некоторых поучений Тихона Задонского... (30 (1), 102).

Из этих цитат видно, как важен для Достоевского образ свт. Тихона. Он противопоставляет его имевшимся дотоле в литературе неудавшимся положительным героям. Костанжогло, преданный его создателем огню, Штольц, коего Достоевский даже «забыл фрамилию», настолько он схематичен и проигрывает по сравнению со своим известным другом, «новые люди» Лопухины и Рахметов - все они со своей задачей «не справляются» и до идеала, нужного русскому читателю, явно не дотягивают. Положительный герой остался в агиографическом жанре древнерусской литературы, но уже, кажется, «не стоит ни гроша» для читателей XIX века, прогонявших нянек своих детей «за то, что те над колыбельками их читали «Богородицу», - об этом пишет Достоевский в «Дневнике писателя» (21, 135). Достоевский берет на себя задачу возвратить читателю его «сокровище», «застав<ить> сознаться, что чистый, идеальный христианин - дело не отвлеченное, а образно реальное, возможное, воочию предстоящее» $(30(1), 68)$. Идеалом для русского человека по-прежнему остается святость, это особенно хорошо стало понятно по восторженной читательской реакции на "Братьев Карамазовых", ибо, как замечает И. Л. Волгин, хоть «святость <и> недостижима (труднодостижима), но без постоянной оглядки на нее недости- жима и «простая порядочность» ${ }^{4}$ Возвращая читателю образ святого и утраченный идеал святости, Достоевский обращает его лицом к Первообразу - ко Христу, и в этом величайший подвиг писателя.

В 1860 году вышло 3-е издание «Сочинений Преосвященного Тихона, епископа Воронежского и Елецкого» в 15 томах, которое, вероятно, было знакомо Достоевскому. Духовное наследие Тихона Задонского, а также сам облик святителя, широко известный к тому времени по многочисленным изданиям его «Жития»" ${ }^{5}$ сыграли немаловажную роль в разрешении вопроса, «которым мучился сознательно или бессознательно всю жизнь» Достоевский, - существования Божьего.

Образ свт. Тихона Задонского в значительной мере явился прототипом святых и праведников Достоевского: епископа Тихона в «Бесах» (пропущенная глава «У Тихона»), наряду с прп. Амвросием Оптинским старца Зосимы в «Братьях Карамазовых», огромное влияние сочинений свт. Тихона прослеживается и в беседах Макара Ивановича Долгорукого с Аркадием в «Подростке».

В образе епископа Тихона в «Бесах» (пропущенная глава «У Тихона») мы видим отражение личностных и даже биографбческих черт свт. Тихона Задонского. В первую очередь это касается отношения как некоторых мирян, так и братии к епископу, находящемуся в классическом положении пророка в своем отечестве. Так, собирая сведения о Тихоне, Ставрогин «услышал от одного осанистого... "клубного" старичка, и старичка богомольного, что “этот Тихон чуть ли не сумасшедший, по крайней мере совершенно бездарное существо и, без сомнения, выпивает"». Подобный «решительный вздор» объясняется тем, что «прожи-

${ }^{4}$ Волгин И. Л. Возвращение билета. М., 2004. С. 264.

${ }^{5}$ Как указывает В. В. Литвинов, «жития святителя в отдельных изданиях были выпущены в количестве свыше 400000 экземпляров (цифра, конечно, приблизительная)» (Литвинов В. В. Указ. соч. С. 643). См., напр.: Жизнь новоявленного угодника Божия Тихона, епископа Воронежского и Елецкого, с присовокуплением избранных мест из его го, всея России чудотворца (СПб., 1862); Житие иже во святых отца нашего Тихона, епископа Воронежского, всея России чудотворца (СПб., 1862) и др. 
вавший на спокое архиерей, по слабости ли характера» или «по непростительной и несвойственной его сану рассеянности, не сумел внушить к себе, в самом монастыре, особливого уважения» $(11,6)$, что вполне соответствует сведениям из жития Тихона Задонского последнего периода его жизни, когда святитель в 1767 году по болезни оставляет управление епархией и поселяется в Задонском Богородицком монастыре. Так, в «Кратких жизнеописаниях русских святых» мы читаем:

Все знали, что нерассудительный настоятель делал свт. Тихону многие оскорбления; следуя его примеру, некоторые монастырские служители тоже оскорбляли его и смеялись вслед ему, когда он проходил по монастырю, а он как будто ничего не слышит, а после скажет: «Богу так угодно, чтоб и служители смеялись надо мною; я и достоин того за грехи мои». При таких случаях он любил повторять: «Прощение лучше мщения» ${ }^{6}$.

Сравним с описанием отношения к епископу Тихону в пропущенной главе «Бесов»:

Говорили, что отец архимандрит, человек суровый и строгий относительно своих настоятельских обязанностей и, сверх того, известный ученостью, даже питал к нему некоторое будто бы враждебное чувство и осуждал его (не в глаза, а косвенно) в небрежном житии и чуть ли не в ереси. Монастырская же братия тоже относилась к больному святителю не то чтоб очень небрежно, а, так сказать, фрамильярно $(11,6)$.

Достоевскому не мог быть неизвестен случай, описанный во всех житиях святителя и нашедший отражение в акафисте Тихону Задонскому - случай с пощечиной. «Раз в гостях у одного знакомого помещика, - пишет прот. А. Лебедев, составитель жизнеописания епископа, свт. Тихон встретился с одним дворянином, человеком вольнодумным и вспыльчивым, который, не ожидая встретить сильных возражений и опровержений со стороны святителя, так разгорячился, что ударил его по щеке. Святитель пал ему в ноги, говоря: "Простите меня Бога ради, что я ввел вас в такое исступление”. Пораженный такой

${ }^{6}$ Архимандрит Игнатий. Краткие жизнеописания русских святых. Кн. II. XVIII в. СПб., 1875. С. 66. кротостью и таким смирением Тихона, гость пришел в такое раскаяние, что, взаимно упав к ногам святителя, зарыдал, умоляя его простить. Разумеется, прощение было даровано, и побежденный кротостью сделался с того времени добрым христианином» ${ }^{7}$. Притом смирение и кротость вовсе не были природными чертами характера святого. В различных изданиях его жития мы находим упоминания о том, что таким образом свт. Тихон боролся со своей горячностью и побеждал ее:

Пылкий, впечатлительный характер требовал долгой борьбы с собою... Сознавая горячность своего характера, свт. Тихон усердно начал молиться Богу, чтобы научиться кротости и смирению, и большим трудом над собою преодолел природную горячность. Случалось ли ему оскорбить или огорчить другого, он спешил прийти к обиженному просить у него прощения, признавая себя виновным ${ }^{8}$.

Случай с пощечиной наиболее показательный, но не единственный в житии святителя, который «и за правильный выговор последнему келейнику из простых мужичков, если замечал его оскорбившимся, кланялся об руку, испрашивая у него прощения ${ }^{9}$. Следовательно, мы видим, что, когда в романе Тихон просит прощения у Ставрогина «за вольная и невольная», этот эпизод имеет реальную основу в житии великого прототипа. Тихон поясняет, что это не просто "монастырская фрормула" (как решил Ставрогин), а твердое убеждение в его, Тихона, личной виновности в том числе и в грехе стоящего перед ним «великого грешника» Ставрогина:

Согрешив, каждый человек уже против всех согрешил и каждый человек хоть чем-нибудь в чужом грехе виноват. Греха единичного нет $(11,26)$.

Эту идею общей виновности «всех за вся» Достоевский вкладывает в уста самых высоких, святых и праведных, своих героев. «...Всякий из нас перед всеми во всем вино-

${ }^{7}$ Прот. А. Лебедев. Святитель Тихон Задонский и всея России Чудотворец его жизнь, писания и прославление // Свт. Тихон Задонский. Собр. соч.: В 5 т. Т. 1. С. 194.

${ }^{8}$ Архимандрит Игнатий. Указ. соч. С. 65

${ }_{9}$ Прот. А. Лебедев. Указ. соч. С. 193. 
ват, а я более всех», - говорит перед смертью Маркел, брат старца Зосимы, герой, явивший высокий пример покаяния $(14,262)$. «...Возьми себя и сделай себя же ответчиком за весь род людской. Друг, да ведь это и вправду так, ибо чуть только сделаешь себя за все и за всех ответчиком искренно, то тотчас увидишь, что оно так и есть в самом деле и что ты-то и есть за всех и за вся виноват. $<. .>$ Помни особенно, что не можешь ничьим судиею быти. Ибо не может быть на земле преступника, прежде чем сам сей судья не познает, что и он такой же точно преступник, как и стоящий перед ним, и что он-то за преступление стоящего перед ним, может, прежде всех и виноват $<. .>$ Как ни безумно на вид, но правда сие. Ибо был бы я сам праведен, может, и преступника, стоящего передо мною, не было бы», - учил старец Зосима (14, 290—291).

Нам представляется вероятным выделить еще ряд мыслей, касающихся христианского осмысления жизни, отношения к ближнему, а также загробного мира, которые высказывают праведники Достоевского, опираясь, на наш взгляд, на сочинения свт. Тихона Задонского.

Для свт. Тихона свойственно радостное, пасхальное восприятие Бога и мира. Сквозные темы его произведений: тема любви, милости Божией, радости соприсутствия Божьего в человеческой жизни. Знать о Христе и молиться Ему, помогать и сострадать ближнему - все это радостно для христианина, «ибо святое Евангелие - это радостная весть, и вера - это сердечное приятие Евангелия, поэтому принимающим его непременно следует духовная радость в сердцах $»^{10}$. Этой радостью проникнуты все его сочинения:

...какая весть может быть нам, грешникам, более приятной, чем слышать проповедуемое отпущение грехов даром, вместо гнева Божиего - милость Божию, вместо проклятия благословение Божие, вместо осуждения - оправдание, вместо ада - отверстое царствие небесное, и с Богом Великим, Святым и Вечным - вечное примирение и общение (IV, 4).

${ }^{10}$ Свт. Тихон Задонский. Об истинном христианстве // Собр. соч.: В 5 т. М., 2003. Т. 4. С. 31. Далее ссылки на сочинения свт. Тихона Задонского даются по этому изданию с указанием тома — римской и страниц - арабскими цифрами.
Тяжко ненавидеть, ибо ненависть мучает, а любить сладко, ибо любовь веселит (IV, 368);

Он заповедует нам друг друга любить: «Сие заповедаю вам, да любите друг друга» (Ин. 15:17). А от любви все добрые дела, как от источника ручьи, проистекут, ибо любовь есть корень добрых дел (1 Кор. 13:1—8, 13) (IV, 372).

Что легче, чем любить? Что слаще, приятнее и удобнее, чем любить? Любви все легко, все не тяжко, все сносно, все удобно. Что прочим тяжко, несносно, неудобно, невозможно - ей все удобно и возможно. Знают о том христиане - ее рачители (IV, 937).

Радость о Господе и милосердие, сострадание ближнему - «краеугольные камни» учения свт. Тихона Задонского. При этом неоднократно повторяется, что ближний наш - это абсолютно любой человек, грешный ли, праведный, единоверный, иноверный - неважно. На любого человека должна распространяться любовь, и свт. Тихон неоднократно обращает внимание на те места Священного Писания, в которых содержится эта мысль:

Благ Он [Христос] и Милосерден - будем друг ко другу добры, сострадательны, будем прощать друг друга, как и Бог во Христе простил нас (Еф. 4:32). Он повелевает солнцу Своему восходить над злыми и добрыми и посылает дождь на праведных и неправедных (Мф. 5:45), - будем и мы творить добро всем, знакомым и незнакомым, своим и чужим, единоверным и иноверным, друзьям и врагам, творящим нам добро и творящим нам зло (II, 61).

Сердце чистое и правое, согласно Святому Писанию... печется о пользе ближнего своего, то есть всякого человека (III, 259).

Любовь всех любит (1 Кор. 13:7) <... [любовь] уподобляется земле, которая и возделываюшим ее, и плююшим на нее подает плоды свои. Таков нрав любви. Она не смотрит на лица, не разбирает чина и родства, близости и дальности, приязни и неприязни; не спрашивает, кто он, нуждающийся в плоде любви: брат или не брат, сродник или несродник, единоплеменник или иноземец, приятель или неприятель, добрый или злой; тому являет действие теплоты своей, кто хочет того и нуждается в том (III, 744). 
Эта проповедь любви не могла не привлечь внимания «всемирно отзывчивого» писателя. О радости и радостном приятии мира говорят «положительно-прекрасные» герои Достоевского. Вспомним слова старца Зосимы:

Други мои, просите у Бога веселья. Будьте веселы, как дети, как птички небесные $(14,290)$.

Данную особенность заметил и митр. Антоний (Храповищкий), неоднократно обращавшийся к творчеству Достоевского:

Возвратившийся к вере Степан Трофимович говорит, умирая, что жизнь есть бесконечная радость. Такого же духа исполнены предсмертные речи старца Зосимы и старичка Макара Долгорукого ${ }^{11}$.

В особенности же хотелось бы остановиться на тех местах сочинений свт. Тихона, где говорится об отношении к греш-

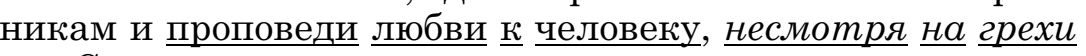
его. Святитель пишет:

Видим, что истинная святость никакими грешниками не гнушается. Истинно святой грех ненавидит, а не грешников, грехами гнушается, а не грешниками. Книжники и фарисеи, мнимой святостью надменные, гнушались грешниками, поэтому и укоряли апостолов: «Для чего Учитель ваш ест и пьет с мылтаряли и грешникали? (Мфр. 9:11). Но Христос, святых Святейший и Источник святыни, никакими грешниками не гнушался. Тому следуют и святые рабы Его, которые от грехов отвращаются, но не от грешников; грехи ненавидят, а грешникам соболезнуют и сострадают. Да постыдится же надменная фрарисейская гордость, которая подобными себе грешниками гнушается! (II, 577).

Знаменитые слова старца Зосимы: «Братья, не бойтесь греха людей, любите человека и во грехе его, ибо сие уж подобие Божеской любви и есть верх любви на земле» (14, 289), вероятно, могли иметь истоком приведенную выше мысль святителя.

С проповедью любви свт. Тихона Задонского, близкой мировоззрению Достоевского, непосредственно связано и его желание всеобшего спасения, что неоднократно подчерки-

${ }_{11}^{11}$ Митр. Антоний (Храповицкий). Словарь к творениям Достоевского. М., 1998. С. 103. вается как в сочинениях епископа, так и в воспоминаниях о нем современников, на основе которых составлены его «Жития».

«По великой любви ко всем людям, свт. Тихон всем желал спасения, и раскольникам, и неверующим, и туркам, и евреям: "Пусть весь мир получит вечное блаженство" 12 , обращал внимание на эту особенность миропонимания святителя архимандрит Игнатий, автор "Кратких жизнеописаний русских святых" (конец XIX века). "Обнимая всех с любовью, святитель Тихон говаривал: "Желал бы я, чтобы не только раскольники, но и турки и все противящиеся Богу получили вечное спасение и блаженство"13, - читаем в "Житии свт. Тихона Задонского", составленном уже в наше время на основе жизнеописания святого, сделанного митрополитом Евгением (Болховитиновым), а также "Записок" Иоанна Ефимова и В. И. Чеботарева, бывших в разное время келейниками епископа. В своем "Келейном молении" несколько молитвенных обращений к Богу из псалмов святитель озаглавил как "Молитвы об общем спасении"'”»14.

«Та же благодать изменяет и делает человека любительным, милосердным, кротким, - считает свт. Тихон, - и та же благодать... воспламеняет и такой любовью к ближним, что хотел бы всех без изъятья вместить в объятья любви своей и всех видеть спасенными» (I, 221-222). Святитель неоднократно подчеркивает, что «спасительная воля Христа» и «честь Христова» требуют заботиться не о своем только, но и о ближнего спасении одновременно:

Тогда любовь ко Христу познается, когда не только о своем, но и о ближнего спасении заботимся. <...> Хочет Христос, чтобы друг о друге заботились и друг другу спасения искали; если хотим любить Христа, должны как себе, так и ближнему искать спасения (III, 755-766).

Эти слова напоминают сходное по своей высоте и любви отношение к ближним, представленное в «поучениях старца Зосимы»:

${ }^{12}$ Архимандрит Игнатий. Указ. соч. С. 67.

13 Жития святителей Митрофана Воронежского и Тихона Задонского. М., 2007. С. 166

${ }^{14}$ Свт. Тихон Задонский. Келейное моление // Избранные труды, письма материалы. М., 2004. Приложение. С. 30. 
Если сам согрешишь и будешь скорбен даже до смерти о грехах твоих или о грехе твоем внезапном, то возрадуйся за другого, возрадуйся за праведного, возрадуйся тому, что если ты согрешил, то он зато праведен и не согрешил $(14,291)$.

К подобному мировосприятию близок, на наш взгляд, и Шатов, направляющий Ставрогина к Тихону. Шатов, который, по его словам, только будет веровать в Бога, не считает себя достойным и готовым обращать к вере Ставрогина, потому рекомендует ему сходить к Тихону. При этом в его словах чувствуется явная забота о своем сопернике (вспомним, что в следующей части Марья Шатова приедет к мужу рожать «ставрогинского ребенка»). Шатов делает акцент на том, что поход к Тихону вовсе не обременит Ставрогина, отмечает, что тот живет совсем недалеко, «здесь, в городе, в черте города, в нашем Ефимьевском Богородском монастыре», и что «к нему ездят и ходят». «Сходите; чего вам? Ну чего вам?» $(10,203)$ — почти упрашивает он Ставрогина. Таким образом, Шатов, передразируя старца Зосиму, считает, что если он не спасется, то будет рад за другого, «великого», грешника, который раскается и спасется, более того, он просит его спастись.

Отсюда же, из желания всеобщего спасения и обращения к Богу, происходит и неотъемлемая составляющая «всемирной отзывчивости» Достоевского - жалость его праведников к самоубийцам и мысль о необходимости молитвы за них. «Самоубийство есть самый великий грех человеческий, - рассуждает Макар Иванович... но судья тут един лишь Господь, ибо Ему лишь известно все, всякий предел и всякая мера. Нам же беспременно надо молиться о таковом грешнике. Каждый раз, как услышишь о таковом грехе, то, отходя ко сну, помолись за сего грешника умиленно, хотя бы только воздохни о нем Богу; даже хотя бы ты и не знал его вовсе, - тем доходнее твоя молитва будет о нем» $(13,310)$. К тому же призывает и старец Зосима:

...горе самим истребившим себя на земле, горе самоубийцам! Мыслю, что уже несчастнее сих и не может быть никого. Грех, рекут нам, о сих Бога молить, и церковь наружно их как бы и отвергает, но мыслю в тайне души моей, что можно бы и за них помолиться. За любовь не осердится ведь Христос.
О таковых я внутренно во всю жизнь молился, исповедуюсь вам в том, отцы и учители, да и ныне на всяк день молюсь $(14,293)$.

Такое понимание заповеди любви к ближнему и желание всеобщего спасения говорит, согласно святоотеческой традиции, о высокол духовнол подвиге. «На высотах подвига духовного», как писал св. прп. Исаак Сирин, сердце разгорается любовью, жалостью и умилением - «о всем творении - о людях, о птицах, о животных, о демонах и о всей твари», - и «вследствие этого о бессловесных, и о врагах Истины, и о вредящих ему ежечасно со слезами приносит молитву, чтобы они были хранимы, и чтобы им быть помилованными» ${ }^{15}$. Эта «жалость ко всей твари» у Достоевского простирается до конца - до жалости к падшим духам. «Я ведь знаю, в конце концов я помирюсь, дойду и я мой квадриллион и узнаю секрет», - говорит черт Ивану Карамазову $(15,82)$.

Известна мысль, что за гробом покаяние уже невозможно, поэтому самоубийцы и лишены церковного отпевания и молитв: последний миг их жизни был отравлен ядом преступления, и для покаяния уже нет времени. Но осознание прожитой греховной жизни, стрелление к изменению своего духовного состояния и к примирению с Богом за гробом вполне возможно. Это верно с точки зрения христианской догматики. «Хотя грешники и не могут изменить своего состояния, не могут сделать никакого добра, тем не менее они могут возжелать освободиться от зла и обpaтиться $\kappa$ добру (курсив мой. - T. К.). Наши молитвы, молитвы Церкви помогают в этом обращении, потому что Бог не хочет смерти грешников, а желает спасения всех людей» ${ }^{16}$, - пишет иер. О. Давыденков в учебнике по догматическолу богословию. Как видим, мысль о всеобщем спасении - мысль Божественная. Этого хочет Бог (безусловно, без насилия над свободной волей человека). Потому праведники Достоевского и молятся за самоубийц и за всех

${ }^{15}$ Цит. по: О. Георгий Флоровский. Блаженство страждущей любви (К 100-летию со дня рождения Ф. М. Достоевского) // Из прошлого русской мысли. М., 1998. С. 70.

${ }^{16}$ Иер. О. Давьденков. Догматическое богословие: Учеб. пособие. М., 2006. C. 413. 
грешников - их сердца наполнены «жалостью ко всей твари», и они это делают, исполняя Господню волю.

Представление о духовном состоянии человека за гробом, в частности о возможности возжелать освободиться от зла и обратиться $\kappa$ добру, связано с самим представлением o загробном мире. Так, в главе «О аде и адском огне, рассуждение мистическое» из поучений старца Зосимы Достоевский утверждает, что адские муки - это муки духовные, муки совести о бессмысленно, без любви растраченной жизни:

Отцы и учители, мыслю: «Что есть ад?» Рассуждаю так: «Страдание о том, что нельзя уже более любить». Раз, в бесконечном бытии, не измеримом ни временем, ни пространством, дана была некоему духовному существу, появлением его на земле, способность сказать себе: «Я есмь, и я люблю». Раз, только раз, дано было ему мгновение любви деятельной, живой, а для того дана была земная жизнь, а с нею времена и сроки, и что же: отвергло сие счастливое существо дар бесценный, не оценило его, не возлюбило, взглянуло насмешливо и осталось бесчувственным. <...> ...Нет уже жизни, и времени более не будет! Хотя бы и жизнь свою рад был отдать за других, но уже нельзя, ибо прошла та жизнь, которую возможно в жертву любви принесть, и теперь бездна между той жизнью и сим бытием. Говорят о пламени адском материальном: не исследую тайну сию и страшусь, но мыслю, что если б и был пламень материальный, то воистину обрадовались бы ему, ибо, мечтаю так, в мучении материальном хоть на миг позабылась бы ими страшнейшая сего мука духовная. Да и отнять у них эту муку духовную невозможно, ибо мучение сие не внешнее, а внутри их. А если б и возможно было отнять, то, мыслю, стали бы оттого еще горше несчастными. Ибо хоть и простили бы их праведные из рая, созерцая муки их, и призвали бы их к себе, любя бесконечно, но тем самым им еще более приумножили бы мук, ибо возбудили бы в них еще сильнее пламень жажды ответной, деятельной и благодарной любви, которая уже невозможна (14, 292-293).

В смиренном же приятии такого безрадостного состояния и заключается, по Достоевскому, некое облегчение страждущих от вечных мук:

...ибо, приняв любовь праведных с невозможностью воздать за нее, в покорности сей и в действии смирения сего, обря- щут наконец как бы некий образ той деятельной любви, которой пренебрегли на земле $(14,293)$.

Представление об адских мучениях как о муках совести также, на наш взгляд, имеет свой источник в книге Тихона Задонского «Об истинном христианстве»:

...в непокаявшемся грешнике пробудится и восстанет совесть (курсив мой. - T. К.), таким его бесстрашием и бесстыдством раздраженная, и чрез всю вечность будет его обли-

чать и мучить за то, что так бесстрашно и бесстыдно против Бога и святого Его закона поступал (IV, 143).

Однако при всем желании всеобщего спасения Достоевский устами старца Зосимы с горечью отмечает, что «есть и во аде пребывшие гордыми и свирепыми, несмотря уже на знание бесспорное и на созерцание правды неотразимой», и их участь гораздо трагичнее:

Злобною гордостью своею питаются, как если бы голодный в пустыне кровь собственную свою сосать из своего же тела начал. Но ненасытимы во веки веков и прощение отвергают, Бога, зовущего их, проклинают. Бога живого без ненависти созерцать не могут и требуют, чтобы не было Бога жизни, чтоб уничтожил себя Бог и все создание свое. И будут гореть в огне гнева своего вечно, жаждать смерти и небытия. Но не получат смерти... $(14,293)$

Эта цитата уже прямо восходит к святителю Тихону:

В будущем веке вечная печаль и мучение: тогда человек увидит свой срам и мерзость свою, и сам себе станет мерзок, самого себя будет ненавидеть, и возжелает в ничто обратиться или умереть, но не сможет, - такое состояние и называется вечной смертью (I, 739).

Здесь будет уместно вспомнить также мотив проснувшейся за гробом совести в «Развязке "Ревизора"» Н. В. Гоголя, кстати, тоже любившего, читавшего и почитавшего Тихона Задонского. «Что ни говори, но страшен тот ревизор, который ждет нас у дверей гроба. Будто не знаете, кто этот ревизор? Что прикидываться? - вопрошает первый комический актер, в одночасье, как в свое время и сам автор, переставший смешить и заговоривший серьезно. Ревизор этот - наша проснувшаяся совесть, которая заставит нас вдруг и разом взглянуть во все глаза на самих 
себя. Перед этим ревизором ничто не укроется, потому что по именному высшему повелению он послан и возвестится о нем тогда, когда уже и шагу нельзя будет сделать назад. Вдруг откроется перед тобою, в тебе же такое страшилище, что от ужаса подымется волос...»17.

Показательно, во-первых, что К. Мочульский «призыв Гоголя» называет «гласом в пустыне», на который «откликнулся Достоевский» ${ }^{18}$.

Показательно, во-вторых, что «гласом вопиющего в пустыне» называют проповеди и сочинения Тихона Задонского $^{19}$, и голос Достоевского часто сравнивают с пророческим ${ }^{20}$.

Великого святого и великого писателя объединяет также миссионерская направленность их служения. Здесь важно обратить внимание на главу «О Священном Писании в жизни отца Зосимы», которая, по свидетельству самого автора, была написана под влиянием сочинений свт. Тихона:

Други и учители, слышал я не раз, а теперь в последнее время еще слышнее стало о том, как у нас иереи Божии, а пуще всего сельские, жалуются слезно и повсеместно на малое свое содержание и на унижение свое и прямо заверяют, даже печатно, - читал сие сам, - что не могут они уже теперь будто толковать народу Писание, ибо мало у них содержания, и если приходят уже лютеране и еретики и начинают отбивать стадо, то и пусть отбивают, ибо мало-де у нас содержания. Господи! Думаю, дай Бог им более сего столь драгоценного для них содержания (ибо справедлива и их жалоба), но воистину говорю: если кто и виноват сему, то наполовину мы сами! Ибо пусть нет времени, пусть он справедливо говорит, что угнетен все время работой и требами, но не все же ведь время, ведь есть же ведь и у него хоть час один во всю-то не-

${ }^{17}$ Гоголь Н. В. Развязка «Ревизора» // Гоголь Н. В. Собр. соч.: В 6 т. T. 4. М., 1952. С. 392-393.

${ }^{18}$ Мочульский K. Духовный путь Гоголя // Н. В. Гоголь и Православие. М., 2004. С. 122.

${ }^{19}$ См., напр.: Свящ. П. Хондзинский. Истинное христианство в житии и трудах свт. Тихона, епископа Задонского // Свт. Тихон Задонский. Избранные труды, письма, материалы. М., 2004. С. 46.

${ }^{20}$ См., напр.: Прот. Г. Флоровский. Указ. соч. С. 69; Митр. Антоний (Храповицкий). Указ. соч. С. $3-5$ и др. делю, чтоб и о Боге вспомнить. Да и не круглый же год работа. Собери он у себя раз в неделю, в вечерний час, сначала лишь только деток, - прослышат отщы, и отщы приходить начнут. Да и не хоромы же строить для сего дела, а просто к себе в избу прими; не страшись, не изгадят они твою избу, ведь всего-то на час один собираешь. Разверни-ка им эту книгу и начни читать без премудрых слов и без чванства, без возношения над ними, а умиленно и кротко, сам радуясь тому, что читаешь им и что они тебя слушают и понимают тебя, сам любя словеса сии, изредка лишь остановись и растолкуй иное непонятное простолюдину слово, не беспокойся, поймут все, все поймет православное сердце! $(14,266)$

Этот прямой призыв к миссионерскому служению, зачастую забытому пастырями «вольнодумного века», почти явно перекликается с «гласом вопиющего в пустыне» воронежского епископа, установившего в кафедральном соборе чтение катехизических поучений, слушать которые народ ходил неохотно:

Сто шестьдесят восемь часов содержит в себе седмица. Отделите из этого числа один час на богоугодное и спасительное дело, и, оставив все житейские попечения, и старые, и молодые, и богатые, и убогие, и отцы, и сыновья, стекайтесь в храм Господень ради слушания слова Божия (I, 532).

«Среднестатистическому» человеку XVIII-XIX веков часа в неделю для Бога было слишком много - в следующем веке Бог был «отнят» на семьдесят лет.

Мы видим, как великий святой и великий писатель согласны в своем миропонимании, любви к человеку и служении Богу. Мы видим, как святость и гениальность сходятся во Христе. 